\title{
Economic Growth and Quality of Institutions in 27 Post-Socialist Economies
}

\section{Structured Abstract}

Purpose: We revisit the relationship between institutional quality and economic growth.

Design/methodology/approach: A panel cointegration methodology and causality analysis are applied to 27 post-socialist economies over the period 1996 to 2016.

Findings: Utilizing the Worldwide Governance Indicators as a means of assessing the quality of institutions we find that in the long run economic growth is positively associated with the rule of law and voice and accountability. In the short run, regulatory quality retains a positive effect, but voice and accountability demonstrate a puzzling negative effect on economic growth that merits further analysis. In exploring the causal dimension of our variables, we provide supporting evidence of the strong links between the quality of institutions and economic growth hence rendering robust results.

Originality/value: To the best of our knowledge, it is the first time that an ARDL methodological framework, which addresses potential endogeneity issues, is used to investigate the relationship between institutional quality and growth in the context of post-socialist economies.

Keywords: Economic growth; Post-Socialist Economies; Institutions; Governance Indicators; Panel Cointegration; Causality.

JEL: O43; P40 


\section{Introduction}

Generally speaking the term "institution" includes the customs and traditions that have existed for a long time as well as the organisations and systems that are important, if not highly critical features of a particular society or a group. In Aristotle's Politics, the City-State a natural institution that is prior in nature to a household and each individual, exists for the supreme benefit of its citizens, their well-being. Broadly, institutions set the rules in societies and influence critically the functioning of national economies as it affects all economic agents. In this context, institutions matter greatly in the realm of economic growth while institutional quality is a key factor in the pursuit of economic growth and prosperity (Acemoglu and Robinson, 2012).

In the 1990s, Williamson (2004) proposed several economic-policy rules known as the Washington Consensus to enable higher rates of economic growth for the developing economies in Latin America. Financial liberalisation, the abolition of (un)necessary regulation, and the provision of secure property rights were inter alia the most "popular" reforms. The economic performance, measured in terms of GDP per capita of the countries that carried out these reforms turned out to be rather disappointing hence, suggesting that the implementation of the envisaged "right policies" was problematic (Ortiz, 2003). A similar prescription that was mainly driven by these policies - stabilisation, privatization and liberalization - was also implemented by postsoviet States in the form of shock reforms. As it transpired, however, these reforms proved to be disastrous causing economic growth to falter (Hamm et al., 2012). Many years later however, institutions were believed to matter more than what "reformers" have previously expected.

In the past 30 years we have witnessed a dramatic transformation of Europe's former communist countries. Effectively, these economies implemented certain policies to 
move closer to free market economies. During this process however, institutional reforms in areas such as governance, competition policy, labor markets, privatization and enterprise restructuring were undermined by opposing political groups that pursued their own vested interests (IMF, 2014).

Prior to 1990-91, all ex-Soviet republics were sharing the same institutional features implied by the nature of the socialist framework of governance. Following the demise of Soviet Union, ex-republics have demonstated fluctuating performance in terms of economic and institutional development and functioning of their political regimes. For instance, Belarus, Russia and Kazakhstan have assumed low scores in the governance indicators classification whereas Latvia, Lithuania and Estonia have achieved higher scores (Melville and Mironyuk, 2016). Economic performance has also shown pronounced variability, with the Baltic States performing better while Moldova, Tajikistan and Kyrgyzstan being the worst performers.

The existing literature on institutional quality and economic growth in post-socialist countries is restricted mostly to descriptive analysis of the development of institutions and economies (Melville and Mironyuk, 2016), conducted more than a decade ago (Matkowski, 2004) and limited to only one particular region (Ahmadov et al., 2013; Aixal and Fabro, 2008; Auzan, 2017; Ghedrovici and Ostapenko, 2013; Gurvich, 2016; Lühiste, 2006).

In view of the scant empirical evidence on the impact of institutions on economic growth, this study purports to revisit and effectively apply the existing theoretical knowledge on the fundamental relationship to a dataset containing practically all postsocialist economies. This research effort supported by recently developed panel cointegration methodologies provides robust and insightful evidence on the institutions-growth nexus in the context of the post-socialist literature. 
The rest of the paper is organized as follows: Section 2 provides the theoretical underpinnings in the extant literature as well as reviews the empirical studies on the link between economic growth and institutions. Section 3 provides an overview of the economic and institutional development in the post-socialist countries while section 4 touches on the methodological framework employed. Section 5 elaborates on the generated evidence whilst section 6 provides the concluding remarks.

\section{Institutions and economic growth: theoretical considerations and empirical} evidence

Central to understanding how institutions influence economic growth is the transaction costs' theory. According to North (1992), good institutions facilitate low transaction costs which in turn galvanize economic growth. In the context of formal institutions, property rights hold a principal position among all economic institutions which is in line with extensive research on its impact on economic growth (see for instance, Acemoglu et al., 2001; Asoni, 2008; Besley and Ghatak, 2009; Kerekes and Williamson, 2008). The rule of law's impact on economic growth can be summarised in three areas as described by Haggard et al. (2008). If individuals are not confident in the equal treatment by the judicial system a) they return to costly private enforcement of contracts; b) rent-seeking behaviour is incentivised by government officials and other economic agents and, therefore, the level of corruption rises; c) rent-seeking and corruption raise barriers to long-term growth such as protectionism and monopolies. For instance, Rigobon and Rodrik (2005) have shown that the rule of law has a causal impact on the level of income.

Regarding the impact of informal institutions on economic growth, Ashraf and Galor (2007) provide evidence suggesting that cultural diffusion and assimilation 
significantly affects economic development whereas, Tabellini (2008) argues that individual values of members in a society influence the well-functioning of government institutions and economic development.

On the empirical front, North and Thomas (1973) were possibly the first to point out that factor accumulation and innovation described by the neoclassical growth model are only rough sources of economic growth and that institutions are the fundamental factors which lead to the differences in their level of development across different countries ${ }^{1}$. Acemoglu et al. (2002) establish a positive relationship between GDP per capita and a proxy of property rights instrumented as an average protection against the risk of expropriation. However, it was not possible to establish causation at that point. Engerman and Sokoloff (2002) developed a theory according to which initial factor endowments such as climate, soil and density of native population influenced the path of institutional development for colonies in South and North America. More specifically, the initial factor endowments influence the level of inequality at the beginning, which, in turn, led to the creation of economic institutions that persist over time. In a later study, Easterly (2007) confirmed that factor endowments predict inequality, which, in turn, predicts long-term economic growth through institutions and schooling.

Several empirical studies showed that variables of good governance such as control of corruption, stability of property rights or democracy are closely correlated with variables such as GDP growth rate per capita, investment or human capital development

\footnotetext{
${ }^{1}$ It should be noted that within the realm of economic development, the importance of technology as a driving force for economic and human development has been emphasized by many scholars (see for instance Ejemeyovwi and Osabuohien 2018).
} 
(see Knack and Keefer, 1995; Barro, 1996). In a later study, Rodrik et al. (2004) tested three competing hypotheses on the determinants of long-term economic growth: geography, international trade and economic integration and institutions. Using panel regressions, Rodrik et al. (2004) find that institutional quality is the only factor which is consistently significant and robust to different model specifications.

In an earlier contribution Rodrik, (1998) provides supporting evidence of the hypothesis that certain institutions such as an independent and competent judiciary, non-corrupt bureaucracy, and social insurance affect positively economic growth in the event of external shocks. In a study that focuses on medium and short-term growth, Hausmann et al. (2004) introduce the concept of growth accelerations and show that changes in political regimes are significant predictors of the accelerations in general. Notably, Hausmann et al. (2004) found that a transition to an autocratic regime has a more favourable effect on growth accelerations than a transition to a democratic regime. In line with several studies, Dollar and Kraay (2003), and Rodrik et al. (2002) assert that political institutions of limited government cause economic growth. Furthermore, Dollar and Kraay (2003) find that cross-country variation in trade, institutions, and their historical and geographical determinants are not very informative of their relative importance for growth in the long run.

On a more critical note, Hausmann et al. (2004) made a distinction between growth accelerations which eventually stop and the ones with a long-lasting effect. While financial liberalisation and external positive trade shocks have a stronger influence on growth accelerations, it is the economic reform and political regime change that increase the likelihood of sustained accelerations. Glaeser et al. (2004) revisit the debate over whether political institutions cause economic growth, or whether, alternatively, growth and human capital accumulation lead to institutional improvement. The authors 
maintain that exploring the causal link between institutions and economic growth has proved extremely difficult due to both conceptual problems with the measurement of institutions $^{2}$ and limitations of econometric techniques. However, the reverse direction, namely that growth in income and human capital causes institutional improvement, is most closely associated with the work of Lipset (1960), who in turn gives credit to Aristotle. Empirically, Lipset's hypothesis that growth leads to better political institutions has received support in the work of Przeworski (1991, 2000) and his associates Alvarez et al. (2000) and Barro (1999). Furthermore, on the significance of political governance Asongu et al. (2019) suggest that political instability can be detrimental to economic growth as investors transfer their capital to economies with more stable political governance. In other words, economies with mediocre political institutions are likely to experience outflow of capital and dwindling investment activity (see Ndikumana et al., 2015; Davies, 2008; Collier et al., 2004).

In addition to the growth accelarations, Hausman et al. (2008) introduced the growth diagnostics tool to quantify how institutions influence short-term economic growth. They show that in each country there are specific distortions, which could not only constrain economic growth but reverse the effects of certain policies due to secondorder effects. A country therefore with a lot of idiosyngratic distortions that hamper economic welfare could divert their efforts in eliminating them to rekindle economic growth.

${ }^{2}$ For instance, Glaeser et al. (2004) maintain that the "government effectiveness" variable is a clear outcome measure which is highly correlated with the level of economic development, rather than political constraints per se. 
Undoubtedly, every country has its unique set of conditions which determine to a large extent the impact of policies and institutions on the economic welfare. In the context of initial dependence, North et al. (2009) by classifying political and institutional regimes in countries as limited access and open access ${ }^{3}$ orders, emphasised the importance of access to economic and political power. In the limited access orders the economic returns and political power distribution is highly skewed towards the elites. The economic superiority of open access regimes is mainly due to being more "flexible and adaptive". However, there is no natural way of development from limited access order to open access order. At the same time, open access orders' institutions and policies would not work in limited access societies due to the different nature of such states.

Commander and Nikoloski (2010), explore whether commonly used measures of institutions such as the political system, the business environment and the perceived business constraints have any significant impact on the performance of countries or firms. In all instances, Commander and Nikoloski (2010) find little evidence of a robust link between measures of institutions and indicators of performance. In line with Glaeser et al. (2004), Commander and Nikoloski (2010) argued that mis-measurement, mis-specification, complexity and non-linearity are all relevant factors for the ambiguity of their results, to the default proposition of institutions affecting performance.

Khan (2010) provides an intriguing perspective on the matter by focusing on the distribution of power in the societies. From his perspective, in developed societies,

${ }^{3}$ North et al. (2009) describe open access orders as highly developed societies with the strong rule of law and property rights, impersonal relationships and decentralised governments, while limited access orders lag behind in all these criteria 
power is distributed towards formal institutions, while in developing ones most of the power is held within informal institutions. Therefore, it is not possible to merely transplant institutions from the developed societies, because the informal powers, if they are strong enough, could disregard formal rules and influence any process. Following that argument, Khan (2010) introduces the growth-stability and trade-off framework, where he shows that if the proposed institutional changes differ from the desired ones by the elites; they will oppose them and cause instability in the society. Therefore, in the short to medium run, all reforms must balance between growth and stability.

Overall, there seems to be broad consensus concerning the importance of institutions for economic performance. However, several studies question the robustness of the growth - institutions nexus pointing to mis-measurement or mis-specification issues while there is some preliminary evidence that the relationship may not be stable over time.

\section{Economic and institutional development in the post-socialist countries}

Before the breakup of the Soviet Union, growth was stagnant in practically all the union states (Sherman, 1994). Imbalances had reached critical levels and oil prices had started dwindling alarmingly. Almost 30 years ago, the Soviet Union was formally split into fifteen independent states with each one of them following their own divergent paths in reforming their institutions. Existing opposing views and country-specific constraints might to some extent help explain the institutional divergence and the progress made so far. 
The transition process of the emerging post socialist economies to a capitalist system of prodcution constitutes an interesting and stimulating research topic to explore. To gain an understanding of the pattern of economic growth and the development of institutional factors over time we have grouped the post-socialist countries into five groups (see Table 1), based on geographical proximity, size of the economies, development of economic ties ${ }^{4}$ and similarities in culture. Broadly, we have applied a similar classification to the one used by IMF.

\section{INSERT TABLE 1 HERE}

Figure 1 depicts the economic growth trajectories of the groups of post-socialist countries. The observed magnitude and fluctuation of the growth rates of GDP over the period 1996-2000 reflect the great divergence in political and economic conditions in these country-groups. In contrast to the turbulence of the first decade of transition, the early and mid-2000s saw uniformly strong growth with the Eastern Europe and the Caucasus group outpacing the other groups during 2000-2007, while the Baltic States suffered the most from the Global Financial Crisis in 2009-10. With favorable global conditions and increasing confidence in convergence with Western Europe, the average

\footnotetext{
${ }^{4}$ There is a high level of interdependency in GDP growth for all the countries whose economies remain interconnected presenting high correlations in GDP growth ranging from 0.88 to 0.99 (Benešová and Smutka, 2016).
} 
growth for the entire sample in the early to mid-2000s was around 6 percent, with no country growing at less than 3 percent annually, a faster rate than most countries have consistently managed before. However, growth in this period was imbalanced, driven by large-scale borrowing for consumption and construction. The inherent vulnerabilities combined with the effects of the Global Financial Crisis had a devastating effect. Output declined by 6 percent on average and ranged up to 18 percent, a more severe impact than in any other region of the world. According to IMF (2014), those countries that took bolder and more front-loaded reforms, Central Europe and then Baltics were rewarded with a faster return to growth.

\section{INSERT FIGURE 1 HERE}

Over the past ten years, average rents from natural resources for the so-called resourcerich countries have ranged from 25 to 50 percent of their GDP. According to Harford and Klein (2005) the countries that have been endowed with a wealth of natural resources are likely less willing to put in place reforms, as these reforms will potentially limit their elites' ability to appropriate those rents. It should also be noted that in countries with higher average oil rents and total natural resources as a percent of GDP government effectiveness is significantly low (Ahmadov et al., 2013).

In resource-poor countries the political challenges that they have faced over the last twenty-five years were more pronounced. Georgia for instance, experienced the Rose Revolution in 2003 while Kyrgyzstan had the Tulip Revolution in 2005 and the Second Kyrgyz Revolution in 2010. . In a nutshell, all these events constitute critical junctures that could lead to the development of new institutions, that potentially impact positively economic growth (Acemoglu et al., 2005).

In terms of institution building, the results of the first years of transition were uneven. Almost all countries suffered from recessions and were vulnerable to crises that swept 
the region in the wake of the Asian crisis in 1997. It can be inferred from Figure 2, the starting point of institutional quality was not the same for all the country groups; it presented a great deal of variation with the Baltic States and Central Europe preserving the highest scores overall.

In Eastern Europe and the Caucasus, the most robust economic performance is exhibited by countries, which grew the most in quality of institutions, Armenia, Azerbaijan and Georgia. However, the extreme case of institutions improvement in Georgia's is not accompanied by the same level of economic growth. South-Eastern Europe is the only region, where all countries performed reasonably well in terms of the quality of institutions. Central Europe is perhaps the most contradicting case. The countries with the highest growth such as Poland and the Slovak Republic exhibit similar economic growth, but their institutional quality presents diverging paths. The Baltic States is the most convergent group regarding economic growth; however, slight differences in growth seem to be inversely related with the change in institutional quality over time. Summing up, our preliminary analysis of the links between economic growth and institutions in the post-socialist countries provides no clear cut results.

Despite a common heritage, post-socialist countries present stark differences on the initial level in institutional quality. The only region which provides some indication of a positive relationship between economic growth and institutional quality is Eastern Europe and the Caucasus. This could be connected to the low base effect while the effect of the soaring oil prices in the period 2000-7 could not be neglected, especially for the resource-rich countries. 
The ensuing economic reforms that were undertaken following the demise of Soviet Union can also be proxied by the Transition Indicators (TI) published by EBRD ${ }^{5}$. In constructing the TI, assessments are made in six key areas: large-scale privatisation, small-scale privatisation, governance and enterprise restructuring, price liberalisation, trade and foreign exchange system, and competition policy. Immediately after their independence, almost all countries started with low TI scores. However, by 1993 the Baltic States swiftly toped the rankings whilst other countries, for instance Turkmenistan, Belarus and Uzbekistan have scored rather poorly. The following plot presents the transition indicators of EBRD by type of reform and by region.

\section{INSERT FIGURE 3 HERE}

As Figure 1 shows, despite the ups and downs, overall the transition period has been one of strong convergence with Western Europe (IMF, 2014), albeit with significant divergence across the country groups.

The Central European countries were more advanced in terms of privatization processes, which led to the private sector representing about $80 \%$ of GDP. Overall, these countries not only exhibited considerable growth in GDP per capita income despite the hardships at the beginning of the transformation (Matkowski, 2004), but they also managed to sustain growth over time. On the contrary, the Balkan countries

\footnotetext{
${ }^{5}$ The EBRD assessed progress in transition through a set of transition indicators. These were used to track reform developments in the countries of operations that primarily included the post-socialist ones in the period 1989-2014. Progress was measured against the standards of industrialised market economies, while EBRD recognises that there is neither a "pure" market economy nor a unique end-point for transition.
} 
have not witnessed a significant change in income levels ranking considerably lower than Central Europe counterparts in terms of their position of Transition Process Index and Human Development Index developed by the EBRD and the United Nations respectively.

\section{Data and methodology}

Our dataset spans the period 1996 to 2016 while certain countries (Bosnia and Herzegovina, Montenegro, Tajikistan and Turkmenistan) were omitted from the sample due to insufficient observations. The key independent variables used in this study are the World Governance Indicators (WGI) as developed by Kaufmann et al. (2011) which practically include six indices, namely regulatory quality, rule of law, political stability and absence of violence, government effectiveness, control of corruption and voice and accountability. Table A1 in the appendix presents the variables used along with the data sources.

Our methodological framework is grounded on cointegration analysis. Traditionally, the presence of unit roots in univariate time series is explored through DF (DickeyFuller) or ADF (Augmented Dickey-Fuller) tests. Recently, more powerful unit root tests have been proposed - such as those by Levin, Lin and Chu, (2002), Im, Pesaran and Shin, (2003) and Hadri, (2000) - which are shown to perform more efficiently than the unit root tests applied to individual series. According to Alexiou, et al., (2016) while these tests are commonly termed 'panel unit root' tests, theoretically speaking, they are simply multiple-series unit root tests that have been applied to panel data structures (where the presence of cross-sections generates "multiple series" out of a single series) 
(p.47). In this paper, both common and individual unit root tests have been utilized i.e. Levin, Lin, Chu (LLC), Im, Pesaran, Shin (IPS), Fisher - ADF and Fisher - PP.

Cointegration methodology purports to investigate the presence of spurious relationships in the event of non-stationary time series. If such a stationary linear relationship is evident then the non-stationary time series are cointegrated which may be interpreted as a long-run equilibrium relationship amongst the variables of interest. In determining whether such a long run relationship exists, we adopt a panel cointegration test proposed by Pedroni (1999) which is based on the two-step residualbased strategy of Engle and Granger (1987).

In this context, seven different statistics that test for panel cointegration are estimated, out of which four - Panel-v, panel-rho, panel non-parametric-t and panel parametric-t are based on a within-dimension and three - group-rho, group non-parametric-t and group parametric-t - on the between-dimension. It should be noted that these tests are applicable to heterogeneous panels and the null hypothesis is that of no cointegration. The formulation for all cointegration tests is couched in the following terms:

$$
y_{i t}=\alpha_{i}+\beta_{1} X_{1, i, t}+\beta_{2} X_{2, i, t}+\ldots \ldots .+\beta_{n} X_{n, i, t}+v_{i t}
$$

where $X_{i, t}$ are the regressors and $n$ the cross-sections. Based on equation (1) a regression on the residuals is then performed:

$$
v_{i, t}=\zeta_{i} v_{i, t-1}+z_{i, t}
$$

The respective estimation process produces the seven different statistics - Panel-v, panel-rho, panel non-parametric-t and panel parametric-t, group-rho, group nonparametric-t and group parametric-t (for a more detailed account of the entire process see Pedroni, 1999). 
We proceed by using the autoregressive distributed lag model (ARDL, p,q) as the emphasis is placed on the need to have consistent and efficient estimates of the parameters in a long-run relationship. According to Pesaran et al. (1999), a dynamic heterogeneous regression can be incorporated into the error correction model using the ARDL approach to cointegration. The general empirical specification of the ARDL model can be expressed in the following form:

$Y_{i t}=\sum_{j=1}^{p} \xi_{i j} y_{i, t-j}+\sum_{j=0}^{q} \zeta_{i j} X_{i, t-j}+v_{t}+\varepsilon_{i t}$

where $X_{i t}$ is a vector of explanatory variables and $v_{t}$ captures the group-specific effect; $i$ denotes cross-sections and $t$ denotes time. Cointegrating series implies that the error term is an $I(0)$ process. By re-parametrizing (3) we can arrive at the error correction specification which assumes the following form:

$$
\Delta Y_{i t}=\lambda_{i} y_{i, t-j}-\mu_{i} X_{i, t-j} \sum_{j=1}^{p-1} \xi_{i j} \Delta y_{i, t-j}+\sum_{j=0}^{q-1} \zeta_{i j} \Delta X_{i, t-j}+v_{t}+\varepsilon_{i t}
$$

The error correction coefficient $\lambda_{i}$ captures the speed of adjustment which is assumed to be negative and statistically significant when, in the presence of a shock, there is convergence to long run equilibrium. Equation 4 can be estimated by three different estimators, the mean group (MG) model of Pesaran and Smith (1995), the Pooled Mean Group (PMG) estimator developed by Pesaran et al. (1999), and the dynamic fixed effects estimator (DFE). All three estimators consider the long-run equilibrium and the heterogeneity of the dynamic adjustment process (Demetriades and Law, 2006) and are computed by maximum likelihood. In this study we consider the advanced version of the Mean Group (MG) estimator, the PMG estimation procedure that is applicable to nonstationary panels. In this context, short-run parameters, intercepts terms, speed of adjustment to the long-run equilibrium values and error variances are permitted to vary across groups (as in MG estimator) whilst for long-run coefficients a restriction of 
equivalence is imposed. This is particularly useful when there are reasons to expect that the long-run equilibrium relationship between the variables is similar across countries or, at least, a sub-set of them. Also important is that the shortrun adjustment can be country-specific, due to the widely different impact of the vulnerability to financial crises, external shocks, and stabilization or reform policies and so on.

All in all, the ARDL model, especially the PMG estimator provides consistent coefficients despite the possible presence of endogeneity because it includes lags of dependent and independent variables (Pesaran et al., 1999). An important assumption for the consistency of the ARDL model is that the resulting residual of the errorcorrection model will be serially uncorrelated, and the explanatory variables can be treated as exogenous. Such conditions can be fulfilled by including the ARDL $(p, q)$ lags for the dependent (p) and independent variables (q) in the error correction form. Third, the relative size of $T$ and $N$ is crucial, since when both are large it allows us to use the dynamic panel technique, which helps to avoid the bias in the average estimators and resolves the issue of heterogeneity. Eberhardt and Teal (2011) argue that the treatment of heterogeneity is central to understanding the growth process. Pesaran and Shin (1999) show that the traditional ARDL approach can be used for long-run analysis. Specifically, the ARDL approach can deal effectively with potential endogeneity issues, remains valid regardless of whether the regressors are exogenous or endogenous and irrespective of whether the variables are $I(0)$ or $I(1)$. However, the presence of $I(2)$ variables renders the methodology inappropriate (Pesaran et al., 2001). In this study, the issue of stationarity has been taken into consideration and a series of unit root tests have been applied, namely, the Levin, Lin and Chu (LLC), and the Im, Pesaran and Shin (IPS) unit root tests. 
The baseline regression model was formulated along the lines suggested by Barro (1996); Góes (2016); Osman et al. (2011) and Alexiou et al. (2018), where the dependent variable is the growth in real GDP (GROWTH) and the explanatory variables consists of INST, a vector including all world governance indicators (WGI), GOV which denotes government expenditure, INV for investment, INF for inflation rate, TRADE as a measure of openness, NAT which denotes natural resources, WORLD that is a measure of world growth, and EDU that measures the level of education. Table A2 in the appendix presents the respective descriptive statistics.

\section{Empirical Results and Discussion}

The analysis gets under way with an assessment of the order of integration of the variables included in the model. Table A3 in the appendix reports the panel unit roots test estimates. An inspection of Table A3 suggests in the variables possess properties of mixed order of integration i.e. $I(0)$ and $I(1)$ but not $I(2)$. It should be stressed that even when individual effects and individual linear trends were considered, no significant differences were observed.

Having established the order of integration we then test for cointegration. All the reported statistics shown in Table A4 in the Appendix, suggest that there is evidence of cointegrating relationships among the variables used. Our evidence was further reinforced by a complementary test - Kao's Residual Cointegration test - which rejected the null hypothesis of no cointegration at the $1 \%$ level of significance.

\section{INSERT TABLE 2 HERE}

In the long run, according to the PMG estimates reported in Table 2 apart from the variable INST that measures the average WGI impact of all institutions, the rule of law 
(ROL) and voice and accountability (VAC) are also significant. In line with a substantial body of research (Butkiewicz and Yanikkaya, 2006; Haggard et al., 2008; Rigobon and Rodrik, 2005; Rodrik et al., 2004), our results indicate that the rule of law benefits economic growth in the post-socialist States. As one could expect, the rule of law which enables the protection of property rights and supports the business activity by stimulating investment. Furthermore, voice and accountability which captures the social dimensions such as freedom of speech, media and level of political participation is also found to affect positively the economic growth. According to Doucouliagos and Ulubaşoğlu, (2008); Rigobon and Rodrik, (2005); Tavares and Wacziarg, (2001) voice and accountability mainly influence economic growth through investment, human capital, lower inflation and higher level of economic freedom.

As far as the control variables are concerned, government expenditure is insignificant and negatively associated with the economic growth in all models. The negative sign might to some extent suggest that policy variables become "irrelevant" in the presence of institutional variables (Acemoglu et al., 2002). Investment is significant bearing a positive sign in models $1,3,6$ and 7 , which lends support to the neoclassical growth model (Solow, 1956). At the same time, inflation exerts a negative impact on growth across all estimated models which is in line with our expectations. In line with Barro (1996), the trade openness was found to be positively associated with the economic growth across all estimated models. Natural resources are found to be insignificant across all models, suggesting that most of the gains in the GDP growth for resourcerich countries practically reflect higher oil and gas prices. The negative effect of education on economic growth may reflect either mis-specification issues or potential interaction with the institutional variables as has been suggested by Acemoglu et al. (2014). Last, the world growth is found to be positively associated with economic 
growth in all models which is in line with our expectations as the sampled economies are reintegrated into the global economy.

As we move along to the short run estimates shown in Table 3, it appears that other institutional factors become more relevant. More specifically, the regulatory quality (REG) is now significant whilst the rule of law (ROL) turned out to be insignificant.

The sign of VAC however has turned negative which appears to be a paradoxical finding, albeit in line with those who have argued that a gradual improvement in institutional quality allows the economy to adjust in a smoother manner to prevent a shock to a system, hence driving instability in the country. Evidently, in the short-run none of the control variables maintains a statistically significant effect apart from the investment and the world growth. It is worth noting that the error correction term in all estimated models is shown to be statistically significant and negative indicating the speed of adjustment to its long-run equilibrium levels.

\section{INSERT TABLE 3 HERE}

In our effort to explore the causal dimension of our key variables we have performed panel causality tests using the WGI variables. Our results indicate a unidirectional causality that runs from ROL, VAC and COC to economic growth (see Table A5 in appendix). In addition, as a robustness check, we have utilised the Transition Progress Index (TI) published by EBRD. In line with the causality tests on WGI, we establish unidirectional causality (see Table A6) between all six components and economic growth, thus, confirming the importance of institutional quality in fostering economic growth. In the case of TI, there is also evidence of the established bi-directional causality, especially in the case GER, TFC and COMPOL which imply a feedback mechanism suggesting that growth goes hand in hand with critical inputs such as 
governance, trade linkages and a functioning foreign exchange system as well as competition policy.

Overall, there is no shadow of a doubt that institutional quality as reflected on the rule of law, the level of corruption, and democratic accountability are instrumental in determining the speed at which developing economies can grow. Equally important however are cultural aspects such as beliefs in the importance of individual effort and morality, that to a certain extent determine the level of trust and respect for each other hence, encouraging welfare-enhancing social interactions (Tabellini, 2010). According to Guiso, et al. (2006), cultural norms may take a long time to evolve. As such, informal institutions could persist for centuries, and even if governments undertake some targeted interventions it could take up to 40 years until some tangible results are realized (Auzan, 2017). It is therefore imperative that policy makers are aware of the inherent interactions between informal social practices and formal institutions so as to set the right policies that can potentially support economic development (for more on the interaction between informal social practices and formal institutions see Freidenberg and Levitsky, 2006; Ellickson, 2007; Grzymala-Busse, 2010).

\section{Concluding remarks}

Nearly a generation has passed since the ex-Soviet economies embarked on a historic transition from central planning to market-based policies. Inevitably, this process proved harder than many envisaged almost 30 years ago. Institutional factors have been difficult to advance in the face of opposition from the insiders with vested interests benefiting from the status quo.

Using a combination of cointegration tests and the ARDL methodology we provide evidence on the short as well as long-run relationships between institutional variables 
and economic growth. Our research adds to the existing evidence on the impact of institutional quality and economic growth. Overall, improvements in regulatory quality could positively contribute to GDP growth. Equally, advancements in the rule of law and voice and accountability are positively associated with economic growth in the long-run. In this context, policymakers would have to implement policies that strengthen and insulate those institutions to reap the long-term benefits for their countries. In the short run however, changes in voice and accountability are associated with declining economic growth which might reflect the fact that gradual improvement in institutional quality provides a breathing space for the economy to adjust in a smoother manner while at the same time it insulates from a shock to the system with adverse consequences. Certainly, building effective institutions should be interpreted as a dynamic process that requires fine-tuning and adjustment of institutions to everchanging technological, social, economic, and political conditions.

Finally, we hold the view that institutional quality has a long-lasting positive effect on economic growth and prosperity. In this respect, Aristotle remains well-timed, as a free citizen will always seek eudaemonia within institutions. The analysis undertaken in this study poses challenging questions for those who envision a viable solution to sustainable economic growth and development. Currently, we do not seem to possess a deep understanding of the forces that may lead to good or bad political equilibria. Effective developmental policies can be introduced once we have recognized and comprehended how these forces interact in different economic and political regimes. Future research could benefit from the use of alternative measures of growth that focus on quality, efficiency and sustainability. 

Journal of Economic Studies 


\section{References}

Acemoglu, D., Johnson, S. and Robinson, J. (2001). 'The colonial origins of comparative development: An empirical investigation', American Economic Review, 91(5), pp. 1369-1401.

Acemoglu, D., Johnson, S. and Robinson, J. (2002). 'Reversal of fortune : geography and institutions in the making of the modern world income distribution', Quarterly Journal of Economics, 117(4), pp. 1231-1294.

Acemoglu, D., Gallego, F. A., and Robinson, J. A. (2014). 'Institutions, human capital, and development', Annual Review of Economics, 6, pp. 875-912.

Acemoglu, D. and Robinson, J. A. (2012). Why Nations Fail, Random House, New York.

Ahmadov, I., Mammadov, J. and Aslanli, K. (2013). Assessment of institutional quality in resource-rich Caspian Basin Countries, MPRA Paper 47430.

Aixal, J. and Fabro, G. (2008). 'Does the impact of institutional quality on economic growth depend on initial income level?', Economic Affairs, 28(3), pp. 45-49.

Alexiou, C., Tsaliki, P. and Tsoulfidis, L. (2016). Classical theory of investment: panel cointegration evidence from thirteen eu countries', Contributions to Political Economy, Vol. 35(1), pp. 39-56.

Alexiou, C., Vogiazas, S. and Nellis, J. (2018). 'Reassessing the relationship between the financial sector and economic growth: dynamic panel evidence', International Journal of Finance and Economics, 23(2), pp. 155-173.

Alvarez, M., J. A. Cheibub, F. Limongi, and A. Przeworski. (2000). Democracy and Development: Political Institutions and Material Well-Being in the World, Cambridge University Press, Cambridge.

Ashraf, Q. and Galor, O. (2007). Cultural assimilation, cultural diffusion and the origin 
of the wealth of nations, CEPR Discussion Paper 6444.

Asongu, S.A., Nting, R. T. \& Osabuohien, E. (2019). One Bad Turn Deserves Another: How Terrorism Sustains the Addiction to Capital Flight in Africa. Journal of Industry, Competition and Trade, DOI: https://doi.org/10. .1007/s10842-019-00303-6.

Asoni, A. (2008). 'Protection of property rights and growth as political equilibria, Journal of Economic Surveys', 22(5), pp. 953-987.

Auzan, A. (2017). 'Revolutions and evolutions in Russia: In search of a solution to the path dependence problem', Russian Journal of Economics, 3(4), pp. 336-347.

Barro, R.J. (1996). Determinants of Economic Growth: A Cross-Country Empirical Study, NBER Working Paper 5698

Benešová, I. and Smutka, L. (2016). The Post-soviet Countries - Development and Structure of Economy: Is there any Potential for Future Regional Integration?, Procedia - Social and Behavioral Sciences, 220, pp. 30-39.

Besley, T. and Ghatak, M. (2009). The de Soto Effect, STICERD, Economic Organisation and Public Policy Discussion Papers Series 008, Suntory and Toyota International Centres for Economics and Related Disciplines, LSE.

Butkiewicz, J.L. and Yanikkaya, H. (2006). 'Institutional quality and economic growth: Maintenance of the rule of law or democratic institutions, or both?', Economic Modelling, 23(4), pp. 648-661. 
Commander, S. and Nikoloski, Z. (2010). Institutions and economic performance: What can be explained? EBRD Working paper No. 21.

Collier, P., Hoeffler, A. and Pattillo, C., (2004). 'Africa's Exodus: Capital Flight and the Brain Drain as Portfolio Decisions'. Journal of African Economies, 13(2), pp. 1554.

Davies, V. (2008), 'Post-war Capital Flight and Inflation'. Journal of Peace Research, 45(4), pp. 519-537.

Demetriades P. and Law, H. (2006). 'Finance, institutions and economic development', International Journal of Finance and Economics, 11, 245-260.

Dollar, D. and Kraay, A. (2003). 'Institutions, trade, and growth', Journal of Monetary Economics, 50(1), pp. 133-162.

Doucouliagos, H. and Ulubaşoğlu, M.A. (2008). 'Democracy and economic growth: A meta-analysis', American Journal of Political Science, 52(1), pp. 61-83.

Easterly, W. (2007). 'Inequality does cause underdevelopment: Insights from a new instrument', Journal of Development Economics, 84(2), pp. 755-776. 
Eberhardt, M., and Teal, F., (2011). 'Econometrics for grumblers: a new look at the literature on cross-country growth empirics', Journal of Economic Surveys, 25(1), 109155.

Ejemeyovwi, J. O. and Osabuohien, E. S. (2018). Investigating the Relevance of Mobile Technology Adoption on Inclusive Growth in West Africa. Contemporary Social Science, DOI: https://doi.org/10.1080/21582041.2018.1503320.

Ellickson, R.C. (2007) 'Order without Law: How Neighbours Settle Disputes (excerpt)', in Anarchy and the Law-The Political Economy of Choice, pp. 658-679.

Engle, R. F. and Granger, C.W.J. (1987). 'Error correction: representation, estimation, and testing', Econometrica, 55(2), pp. 251-276.

Engerman, S. and Sokoloff, K. (2002). 'Factor endowments, inequality, and paths of development among new world economies', Economía, 3(1), pp. 41-109.

Freidenberg, F. and Levitsky, S. (2006) 'Informal institutions and party organization in Latin America', in Informal Institutions and democracy. Lessons from Latin America. pp. $178-197$.

Ghedrovici, O. and Ostapenko, N. (2013). 'The glaring socioeconomic meltdown in post-soviet ukraine , moldova , and belarus : a distorted mindset in search of a way out', International Journal of Business and Social Research, 3(5), pp. 202-211.

Góes, C. (2016). 'Institutions and growth: A GMM/IV Panel VAR approach', Economics Letters, 138, pp. 85-91.

Glaeser, E.L., La Porta, R., Lopez-de-Silanes, F. and Shleifer, A. (2004). 'Do institutions cause growth?', Journal of Economic Growth, 9(3), pp. 271-303.

Grzymala-Busse, A. (2010) 'The Best Laid Plans: The Impact of Informal Rules on Formal Institutions in Transitional Regimes', Studies in Comparative International Development, 45(3), pp. 311-333. 
Gurvich, E. (2016). 'Institutional constraints and economic development', Russian Journal of Economics, 2(4), pp. 349-374.

Guiso, L., Sapienza, P. and Zingales, L. (2006) 'Does Culture Affect Economic Outcomes?', Journal of Economic Perspectives, 20(2), pp. 23-48.

Hadri, K (2000). 'Testing for stationarity in heterogeneous panel data', Econometrics Journal, 3, 148-161.

Haggard, S., MacIntyre, A. and Tiede, L. (2008). 'The rule of law and economic development', Annual Review of Political Science, 11(1), pp. 205-234.

Hamm, P., King, L.P. and Stuckler, D. (2012). 'Mass privatization, state capacity, and economic growth in post-communist countries', American Sociological Review, 77(2), pp. 295-324.

Harford, T. and Klein, M. (2005). Aid and the Resource Curse, The World Bank Group, Note 291, Washington, DC.

Hausmann, R., Pritchett, L. and Rodrik, D. (2004). Growth Accelerations, NBER Working Paper 10566.

Hausmann, R., Rodrik, D. and Velasco, A. (2005). Growth diagnostics, The John F. Kennedy School of Government, Harvard University, Massachusetts.Im, K.S., Hashem Pesaran, M. and Shin, Y. (2003). 'Testing for unit roots in heterogeneous panels', Journal of Econometrics, 115, pp. 53-74.

International Monetary Fund (2014). 25 Years of Transition Post-Communist Europe and the IMF, Regional Economic Issues, Special Report, October 2014.

Kaufmann, D., Kraay, A. and Mastruzzi, M. (2011). 'The worldwide governance indicators: Methodology and analytical issues', Hague Journal on the Rule of Law, 3(2), pp. $220-246$.

Kerekes, C. and Williamson, C. (2008). 'Unveiling de Soto's mystery: property rights, 
capital formation, and development', Journal of Institutional Economics, 4(03), p. 299325.

Khan, M. (2010). Political settlements and the governance of growth-enhancing institutions, SOAS Working Paper.

Knack, S. and Keefer, P. (1995). 'Institutions and economic performance: cross-country tests using alternative institutional measures', Economics and Politics, 7(3), pp. 207227.

Levin, A., Lin, C.-F. and Chu, C.-S.J. (2002). 'Unit Root tests in panel data: asymptotic and finite sample properties', Journal of Econometrics, 108, pp. 1-24.

Lipset, S. M. (1960). Political Man: The Social Bases of Politics, Doubleday \& Company

Lühiste, K. (2006). 'Explaining trust in political institutions: Some illustrations from the Baltic states', Communist and Post-Communist Studies, 39(4), pp. 475-496.

Matkowski, Z. (2004). 'Postsocialist countries: macroeconomic performance, growth prospects, and social welfare', Eastern European Economics, 42(3), pp. 44-80.

Melville, A. and Mironyuk, M. (2016). 'Bad enough governance: State capacity and quality of institutions in post-Soviet autocracies', Post-Soviet Affairs, 32(2), pp. 132151.

Ndikumana, L., Boyce, J. and Ndiaye, A.S. (2015). Capital Flight: Measurement and Drivers, in Ajayi, S. I. and L. Ndikumana (Eds), Capital Flight from Africa: Causes, Effects, and Policy Issues, Oxford: Oxford University Press, 15-54.

North, D.C. (1992). 'Transaction costs, institutions, and economic performance', Journal of Institutional and Theoretical Economics, 140, pp. 7-17.

North, D. C. and Thomas, R. P. (1973). The rise of the western world: A new economic history, Cambridge: Cambridge University Press. 
North, D.C., Wallis, J.J. and Weingast, B.R. (2009). Violence and social orders: A conceptual framework for interpreting recorded human history. Cambridge: Cambridge University Press.

Ortiz, G. (2003). Overcoming Reform Fatigue, Finance and Development, IMF, pp. $14-17$.

Osman, R., Alexiou, C. and Tsaliki, P. (2011). 'The role of institutions in economic development', International Journal of Social Economics, 39(1/2), pp. 142-160.

Pedroni, P. (2004). 'Panel cointegration: asymptotic and finite sample properties of pooled time series tests with an application to the PPP hypothesis', Econometric Theory, 20(3), pp. 597-625.

Pesaran, M.H., Shin, Y. and Smith, R.P. (1999). 'Pooled mean group estimation of dynamic heterogeneous panels', Journal of the American Statistical Association, 94(446), pp. 621-634.

Pesaran, M.H. and Smith, R. (1995). 'Estimating long-run relationships from dynamic heterogeneous panels', Journal of Econometrics, 68(1), pp. 79-113.

Przeworski, A. Michael E. Alvarez; Jose Antonio Cheibub; Fernando Limongi (2000). Adam Przeworski, ed. Democracy and Development; Political Institutions and WellBeing in the World, 1950-1990. New York: Cambridge University Press.

Przeworski, A. (1991). Democracy and the market; political and economic reforms in eastern europe and latin america. New York: Cambridge University Press.

Rigobon, R. and Rodrik, D. (2005). 'Rule of law, democracy, openness, and income', Economics of Transition, 13(3), pp. 533-564.

Rodrik, D. (1998). Where Did All the Growth Go? External Shocks, Growth Collapses and Social Conflicts, NBER Working Paper, 6350, pp. 385-412.

Rodrik, D., Subramanian, A. and Trebbi, F. (2004). 'Institutions rule: The primacy of 
institutions over geography and integration in economic development', Journal of Economic Growth, 9(2), pp. 131-165.

Sherman, H.J. (1994). 'Rise and fall of the Soviet Union', International Journal of Political Economy, 24(1), pp. 5-18.

Solow, R. (1956). 'A Contribution to the theory of economic growth', Quarterly Journal of Economics, 70, pp. 65-94.

Tabellini, G. (2008). 'Presidential address: Institutions and culture', Journal of the European Economic Association, 6(2-3), pp. 255-294.

Tabellini, G. (2008) Presidential address: Institutions and culture, Journal of the European Economic Association, 6(2-3), pp. 255-294.

Tavares, J. and Wacziarg, R. (2001). 'How democracy affects growth', European Economic Review, 45(8), pp. 1341-1378.

Williamson, J. (2004). 'The strange history of the Washington consensus', Journal of Post Keynesian Economics, 27(2), pp. 195-206. 


\section{FIGURES}

Figure 1: Real GDP growth patterns of post-socialist countries $(1996$ - 2016)

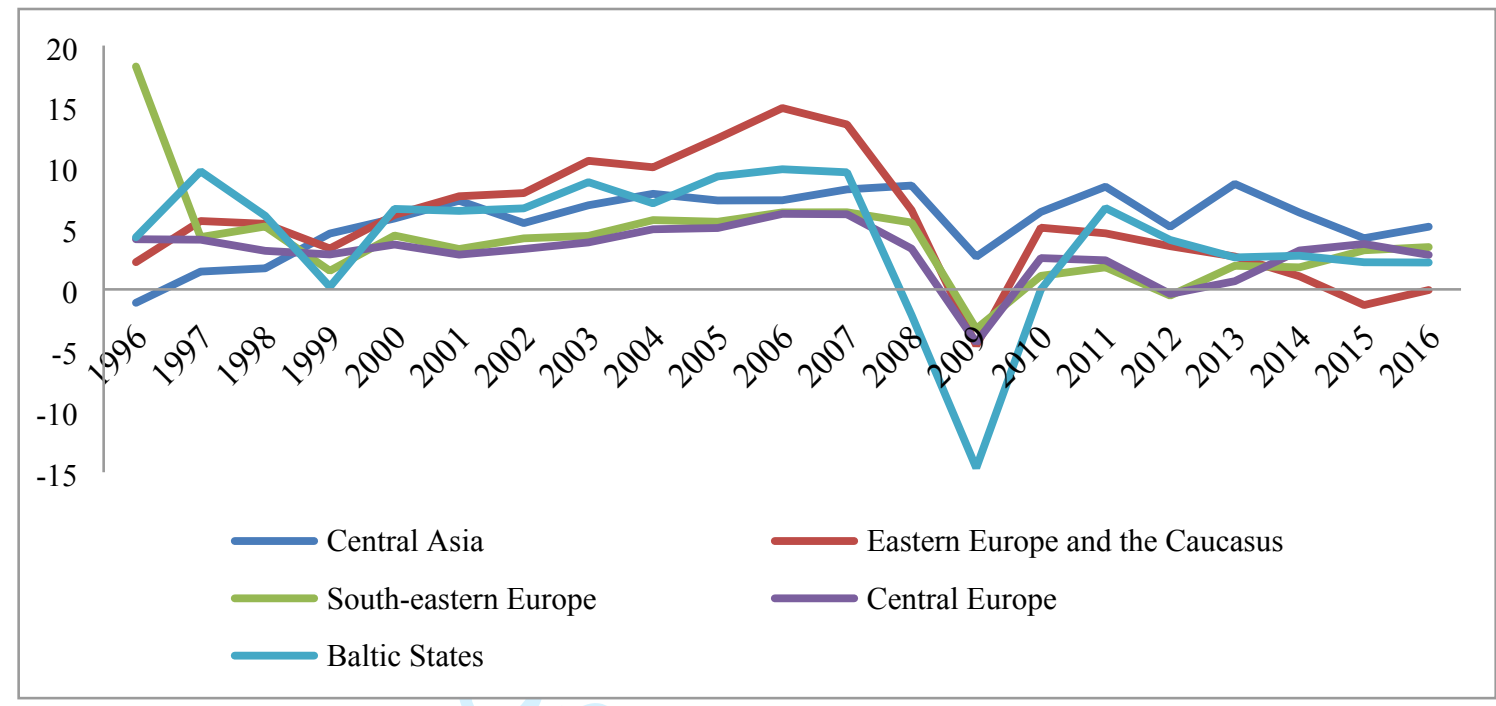

Source: World Bank

INSERT FIGURE 2 HERE

Figure 2: Institutional quality of post-socialist countries (average of WGI)

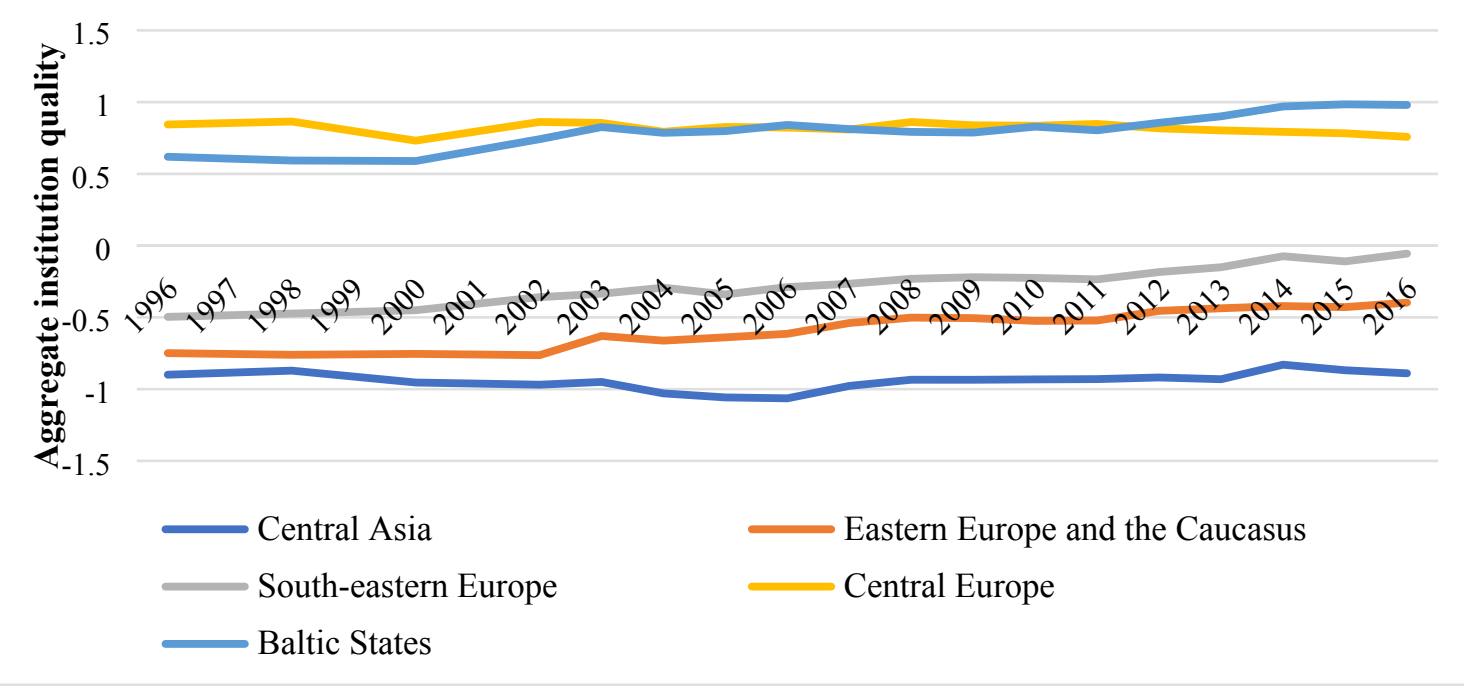

Source: World Bank \& authors' calculations. 
Figure 3: Transition indicators of EBRD by reform type and by region in 1989-2013.

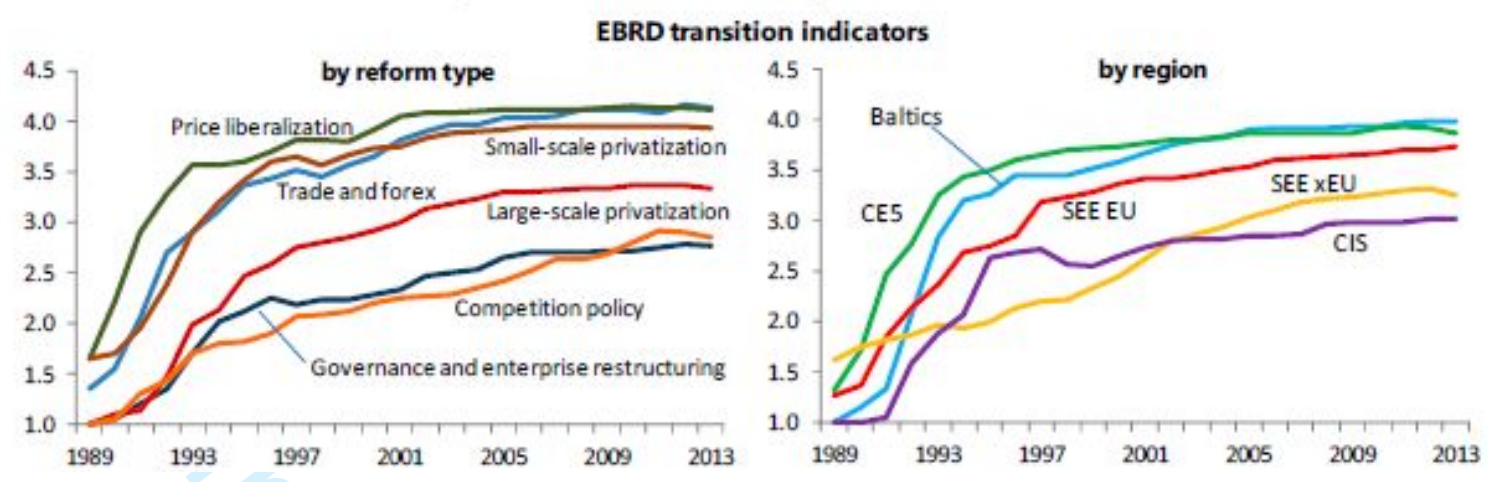

Source: IMF (2014)

\section{TABLES}

Table 1: Groups of post-socialist countries

\begin{tabular}{|l|l|}
\hline Group & List of countries \\
\hline Central Asia & $\begin{array}{l}\text { Kazakhstan; Kyrgyz Republic; Tajikistan; } \\
\text { Turkmenistan; Uzbekistan. }\end{array}$ \\
\hline $\begin{array}{l}\text { Eastern Europe and } \\
\text { Caucasus }\end{array}$ & $\begin{array}{l}\text { Armenia; Azerbaijan; Belarus; Georgia; Moldova; } \\
\text { Russian Federation; Ukraine. }\end{array}$ \\
\hline South-Eastern Europe & $\begin{array}{l}\text { Albania; Bosnia and Herzegovina; Bulgaria; } \\
\text { Croatia; FYROM; Montenegro; Romania }\end{array}$ \\
\hline Central Europe & $\begin{array}{l}\text { Czech Republic; Hungary; Poland; Slovak Republic; } \\
\text { Slovenia }\end{array}$ \\
\hline Baltic States & Estonia; Latvia; Lithuania \\
\hline
\end{tabular}


Table 2: Long run estimates (PMG)

\begin{tabular}{|c|c|c|c|c|c|c|c|}
\hline Model & 1 & 2 & 3 & 4 & 5 & 6 & 7 \\
\hline \multicolumn{8}{|c|}{ Long-Run estimates } \\
\hline \multirow[t]{2}{*}{ INST } & $1.474^{*}$ & & & & & & \\
\hline & $(0.81)$ & 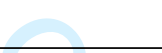 & & & & & \\
\hline \multirow[t]{2}{*}{ REG } & & -0.876 & & & & & \\
\hline & & $(0.59)$ & & & & & \\
\hline \multirow[t]{2}{*}{ ROL } & & $\angle$ & $1.442 * *$ & & & & \\
\hline & & 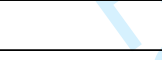 & $(0.652)$ & & & & \\
\hline \multirow[t]{2}{*}{ POLST } & & & & 0.559 & & & \\
\hline & & & & $(0.545)$ & & & \\
\hline \multirow[t]{2}{*}{ GOVEF } & & & 8 & & -0.724 & & \\
\hline & & & 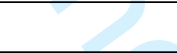 & & $(0.58)$ & & \\
\hline \multirow[t]{2}{*}{$\mathrm{COC}$} & & & & & & -0.303 & \\
\hline & & & & 3 & & $(0.656)$ & \\
\hline \multirow[t]{2}{*}{ VAC } & & & & 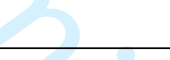 & & & $2.298 * * *$ \\
\hline & & & & 80 & & & $(0.784)$ \\
\hline \multirow[t]{2}{*}{ GOV } & -0.066 & 0.029 & -0.075 & 0.0029 & -0.0424 & 0.0121 & 0.0227 \\
\hline & $(0.087)$ & $(0.068)$ & $(0.087)$ & $(0.082)$ & $(0.0653)$ & $(0.0772)$ & $(0.0871)$ \\
\hline \multirow[t]{2}{*}{ INV } & $0.064 * *$ & 0.0429 & $0.0598 * *$ & 0.0392 & 0.0292 & $0.0509^{*}$ & $0.0578 * *$ \\
\hline & $(0.027)$ & $(0.0282)$ & $(0.0264)$ & $(0.0277)$ & $(0.0278)$ & $(0.0272)$ & $(0.026)$ \\
\hline \multirow[t]{2}{*}{ INF } & $-0.036 * * *$ & $-0.016 * * *$ & $-0.036 * * *$ & $-0.026 * * *$ & $-0.026 * * *$ & $-0.023 * * *$ & $-0.030 * * *$ \\
\hline & $(0.009)$ & $(0.0045)$ & $(0.0092)$ & $(0.0074)$ & $(0.0059)$ & $(0.0058)$ & $(0.0078)$ \\
\hline \multirow[t]{2}{*}{ TRADE } & $0.063 * * *$ & $0.045^{* * *}$ & $0.0607 * * *$ & $0.0572 * * *$ & $0.0422 * * *$ & $0.0497 * * *$ & $0.052 * * *$ \\
\hline & $(0.0091)$ & $(0.009)$ & $(0.0092)$ & $(0.0090)$ & $(0.0097)$ & $(0.0101)$ & $(0.00977)$ \\
\hline \multirow[t]{2}{*}{ NAT } & -0.0119 & -0.0737 & -0.117 & -0.0632 & -0.0058 & -0.091 & -0.045 \\
\hline & $(0.0787)$ & $(0.094)$ & $(0.0839)$ & $(0.0907)$ & $(0.0869)$ & $(0.0857)$ & $(0.0952)$ \\
\hline \multirow[t]{2}{*}{ EDU } & $-0.076^{* * *}$ & $-0.054 * * *$ & $-0.085^{* * *}$ & $-0.066^{* * *}$ & $-0.057 * * *$ & $-0.063 * * *$ & $-0.067 * * *$ \\
\hline & $(0.011)$ & $(0.011)$ & $(0.0114)$ & $(0.0118)$ & $(0.011)$ & $(0.0109)$ & $(0.0112)$ \\
\hline \multirow[t]{2}{*}{ WORLD } & $1.106 * * *$ & $0.802 * * *$ & $1.060 * * *$ & $0.939 * * *$ & $0.828 * * *$ & $0.919 * * *$ & $1.005^{* * *}$ \\
\hline & $(0.113)$ & $(0.126)$ & $(0.117)$ & $(0.125)$ & $(0.122)$ & $(0.121)$ & $(0.114)$ \\
\hline
\end{tabular}

Note: Robust standard errors in parentheses: ${ }^{* * *} \mathrm{p}<0.01,{ }^{* *} \mathrm{p}<0.05,{ }^{*} \mathrm{p}<0.1$ 
Table 3: Short run estimates (PMG)

\begin{tabular}{|c|c|c|c|c|c|c|c|}
\hline Model & 1 & 2 & 3 & 4 & 5 & 6 & 7 \\
\hline & \multicolumn{7}{|c|}{ Short-Run estimates } \\
\hline \multirow{2}{*}{$\begin{array}{c}\text { Error } \\
\text { Correction }\end{array}$} & $-0.81 * * *$ & $-0.76^{* * *}$ & $-0.78 * * *$ & $-0.75 * * *$ & $-0.76 * * *$ & $-0.76 * * *$ & $-0.77 * * *$ \\
\hline & $(0.0624)$ & $(0.0609)$ & $(0.0619)$ & $(0.0574)$ & $(0.0647)$ & $(0.0662)$ & $(0.0557)$ \\
\hline \multirow[t]{2}{*}{ D.INST } & 3.684 & & & & & & \\
\hline & $(2.443)$ & & & & & & \\
\hline \multirow[t]{2}{*}{ D.REG } & 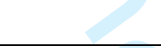 & $3.551^{*}$ & & & & & \\
\hline & & $(2.11)$ & & & & & \\
\hline \multirow[t]{2}{*}{ D.ROL } & & & 1.489 & & & & \\
\hline & & 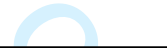 & $(1.809)$ & & & & \\
\hline \multirow[t]{2}{*}{ D.POLST } & & 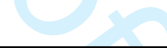 & & 0.818 & & & \\
\hline & & r & & $(0.798)$ & & & \\
\hline \multirow[t]{2}{*}{ D.GOVEF } & & & $\theta$ & & 1.049 & & \\
\hline & & 政 & 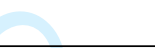 & & $(1.706)$ & & \\
\hline \multirow[t]{2}{*}{ D.COC } & & & - & & & 1.849 & \\
\hline & & & 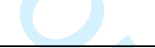 & & & $(2.884)$ & \\
\hline \multirow[t]{2}{*}{ D.VAC } & & & 2 & & & & $-3.675^{*}$ \\
\hline & & & 8 & & & & $(2.09)$ \\
\hline \multirow[t]{2}{*}{ D.GOV } & -0.156 & -0.263 & -0.164 & -0.132 & -0.337 & -0.336 & -0.144 \\
\hline & $(0.266)$ & $(0.27)$ & $(0.275)$ & $(0.248)$ & $(0.254)$ & $(0.244)$ & $(0.265)$ \\
\hline \multirow[t]{2}{*}{ D.INV } & $0.381 * * *$ & $0.401 * * *$ & $0.381 * * *$ & $0.428 * * *$ & $0.434 * * *$ & $0.432 * * *$ & $0.425 * * *$ \\
\hline & $(0.0776)$ & $(0.079)$ & $(0.0721)$ & $(0.0798)$ & $(0.0792)$ & $(0.0771)$ & $(0.0815)$ \\
\hline \multirow[t]{2}{*}{ D.INF } & -0.0283 & -0.029 & -0.0334 & -0.0262 & -0.0447 & -0.0397 & -0.00996 \\
\hline & $(0.0484)$ & $(0.0534)$ & $(0.0513)$ & $(0.0481)$ & $(0.0488)$ & $(0.0504)$ & $(0.0497)$ \\
\hline \multirow[t]{2}{*}{ D.TRADE } & -0.00781 & 0.0153 & -0.022 & -0.00162 & -0.0128 & 0.00483 & $5.12 \mathrm{E}-05$ \\
\hline & $(0.0392)$ & $(0.0412)$ & $(0.04)$ & $(0.0357)$ & $(0.0347)$ & $(0.0398)$ & $(0.038)$ \\
\hline \multirow[t]{2}{*}{ D.NAT } & 1.071 & 1.067 & 1.265 & 1.52 & 1.166 & 1.995 & 0.833 \\
\hline & $(2.534)$ & $(2.49)$ & $(2.586)$ & $(2.586)$ & $(2.259)$ & $(2.637)$ & $(2.462)$ \\
\hline \multirow[t]{2}{*}{ D.EDU } & -0.0351 & 0.0437 & 0.0277 & 0.00284 & -0.0617 & -0.0425 & -0.00343 \\
\hline & $(0.0821)$ & $(0.0694)$ & $(0.0671)$ & $(0.0669)$ & $(0.0759)$ & $(0.0946)$ & $(0.0591)$ \\
\hline \multirow[t]{2}{*}{ D.WORLD } & $0.275^{*}$ & $0.342 * * *$ & $0.263^{*}$ & $0.404 * * *$ & $0.473 * * *$ & $0.374 * *$ & $0.287 * *$ \\
\hline & $(0.152)$ & $(0.129)$ & $(0.151)$ & $(0.132)$ & $(0.134)$ & $(0.146)$ & $(0.14)$ \\
\hline \multirow[t]{2}{*}{ Constant } & $6.016 * * *$ & $11.15 * * *$ & $7.121 * * *$ & $7.748 * * *$ & $12.20 * * *$ & $9.638 * * *$ & $3.782 * * *$ \\
\hline & $(0.612)$ & $(0.943)$ & $(0.671)$ & $(0.656)$ & $(1.033)$ & $(0.857)$ & $(0.6)$ \\
\hline Obs & 440 & 440 & 440 & 440 & 440 & 440 & 440 \\
\hline Log LL & -782.6 & -784 & -779.5 & -770.4 & -775.6 & -770.3 & -780.7 \\
\hline
\end{tabular}

Notes: Robust standard errors in parentheses: ${ }^{* * *} \mathrm{p}<0.01,{ }^{* *} \mathrm{p}<0.05,{ }^{*} \mathrm{p}<0.1$. Lag level of 1 . 


\section{Appendix}

Table A1: Variables

\begin{tabular}{|c|c|}
\hline Variables & Definitions \\
\hline \multicolumn{2}{|l|}{ Quality of Institutions (WGI) } \\
\hline INST & WGI average \\
\hline ROL & Rule of law \\
\hline VAC & Voice and accountability \\
\hline $\mathrm{COC}$ & Control of corruption \\
\hline REG & Regulatory quality \\
\hline GOVEF & Government effectiveness \\
\hline \multicolumn{2}{|l|}{ Transition Indicators (TI) } \\
\hline LSPRIV & Large-scale privatisation \\
\hline SSPRIV & Small-scale privatisation \\
\hline GER & Governance and enterprise restructuring \\
\hline PRLIB & Price liberalisation \\
\hline TFX & Trade and foreign exchange system \\
\hline COMPOL & Competition policy \\
\hline \multicolumn{2}{|l|}{ Control variables } \\
\hline GOV & Government expenditure (\% of GDP) \\
\hline INV & Gross capital formation ( $\%$ of GDP) \\
\hline INF & Consumer prices index annual \% \\
\hline TRADE & Sum of exports and imports as \% of GDP \\
\hline NAT & Natural resources as \% of GDP \\
\hline EDU & $\begin{array}{l}\text { School enrolment, tertiary gross (\%) lagged } 5 \\
\text { years }\end{array}$ \\
\hline WORLD & Aggregate real GDP annual world growth \\
\hline Real GDP & Natural logarithm of GDP, constant 2010 US\$ \\
\hline
\end{tabular}

Sources: World Bank, EBRD \& IMF; the transition indicators of EBRD refer to the period 1996-2014; The year 2014 was the last year of these indicators as EBRD developed a new approach to track transition and discontinued publishing the transition indicators. 
Table A2: Descriptive statistics

\begin{tabular}{|l|c|c|c|c|c|c|}
\hline & Mean & St Dev & Min & Max & Kurtosis & Skewness \\
\hline GROWTH & 4.45 & 6.24 & -16.7 & 88.96 & 61.4 & 4.46 \\
\hline GOV & 17.17 & 14.13 & 7.32 & 29.94 & -0.42 & -0.4 \\
\hline INV & 24.82 & 6.67 & 5.39 & 57.99 & 2.57 & 1 \\
\hline INF & 11.61 & 51.08 & -8.53 & 1058.37 & 356.8 & 17.8 \\
\hline TRADE & 99.99 & 31.57 & 36.55 & 199.68 & -0.31 & 0.46 \\
\hline NAT & 5.93 & 11.28 & 0 & 82.53 & 10.99 & 3.06 \\
\hline VAC & -0.17 & 1.01 & -2.26 & 1.28 & -1.05 & -0.39 \\
\hline POLST & -0.04 & 0.77 & -2.11 & 1.31 & -0.75 & -0.33 \\
\hline GOVEF & -0.17 & 0.75 & -1.64 & 1.19 & -1.16 & 0.12 \\
\hline REG & -0.05 & 0.96 & -2.34 & 1.7 & -0.6 & -0.48 \\
\hline COC & -0.33 & 0.8 & -1.74 & 1.3 & -1.14 & 0.28 \\
\hline ROL & -0.33 & 0.74 & -1.67 & 1.37 & -0.97 & 0.29 \\
\hline EDU5 & 38.56 & 19.18 & 8.8 & 89.11 & -0.6 & 0.59 \\
\hline WORLD & 4.01 & 1.37 & 0.1 & 6.46 & 1.28 & -0.53 \\
\hline
\end{tabular}


Table A3: Unit root tests

\begin{tabular}{|c|c|c|c|c|c|c|c|c|}
\hline \multirow{2}{*}{ Variables } & \multicolumn{2}{|c|}{ Levin, Lin Chu } & \multicolumn{2}{|c|}{$\begin{array}{c}\text { Im, Pesaran and } \\
\text { Shin }\end{array}$} & \multicolumn{2}{|c|}{ Fisher ADF } & \multicolumn{2}{|c|}{ Fisher PP } \\
\hline & Stat & p-value & Stat & $\begin{array}{c}\mathrm{p}- \\
\text { value }\end{array}$ & Stat & p-value & Stat & $\begin{array}{c}\mathrm{p}- \\
\text { value }\end{array}$ \\
\hline GROWTH & -8.98 & 0.00 & -8.86 & 0.00 & 189.89 & 0.00 & 491.21 & 0.00 \\
\hline $\mathrm{D}(\mathrm{VAC})$ & -12.1 & 0.00 & -12.07 & 0.00 & 216.61 & 0.00 & 223.08 & 0.00 \\
\hline POLST & -4.1 & 0.00 & -4.11 & 0.00 & 104.18 & 0.00 & 67.87 & 0.09 \\
\hline $\mathrm{D}(\mathrm{GOV}$ & -10.9 & 0.00 & -12.61 & 0.00 & 233.86 & 0.00 & 329.99 & 0.00 \\
\hline $\mathrm{D}(\mathrm{REG})$ & -10.12 & 0.00 & -11.98 & 0.00 & 225.87 & 0.00 & 273.32 & 0.00 \\
\hline $\mathrm{D}(\mathrm{COC})$ & -17.8 & 0.00 & N/A & N/A & 362.07 & 0.00 & 385.57 & 0.00 \\
\hline $\mathrm{D}(\mathrm{ROL})$ & -9.5 & 0.00 & -9.25 & 0.00 & 174.69 & 0.00 & 202.53 & 0.00 \\
\hline D(INST) & -8.58 & 0.00 & -10.63 & 0.00 & 200.11 & 0.00 & 241.97 & 0.00 \\
\hline $\mathrm{D}(\mathrm{EDU})$ & -12.35 & 0.00 & -7.84 & 0.00 & 140.4 & 0.00 & 121.01 & 0.00 \\
\hline WORLD & -13.62 & 0.00 & -8.41 & 0.00 & 161.21 & 0.00 & 161.76 & 0.00 \\
\hline GOV & -4.22 & 0.00 & -4.19 & 0.00 & 99.46 & 0.00 & 106.14 & 0.00 \\
\hline INV & -3.17 & 0.00 & -2.93 & 0.00 & 86.12 & 0.00 & 66.38 & 0.12 \\
\hline $\mathrm{INF}$ & -12.05 & 0.00 & -9.92 & 0.00 & 207.9 & 0.00 & 261.84 & 0.00 \\
\hline TRADE & -4.82 & 0.00 & -5.12 & 0.00 & 118.15 & 0.00 & 76.67 & 0.02 \\
\hline NAT & -2.61 & 0.00 & -1.73 & 0.04 & 85.72 & 0.00 & 89.05 & 0.00 \\
\hline
\end{tabular}


Table A4: Cointegration tests

\begin{tabular}{|l|cccccccc|}
\hline \multirow{5}{*}{} & & $\begin{array}{c}\text { INST, } \\
\text { EDU }\end{array}$ & $\begin{array}{c}\text { REG, } \\
\text { EDU }\end{array}$ & $\begin{array}{c}\text { ROL, } \\
\text { EDU }\end{array}$ & $\begin{array}{c}\text { POLST, } \\
\text { EDU }\end{array}$ & $\begin{array}{c}\text { GOVEF, } \\
\text { EDU }\end{array}$ & $\begin{array}{c}\text { COC, } \\
\text { EDU }\end{array}$ & $\begin{array}{c}\text { VAC, } \\
\text { EDU }\end{array}$ \\
\hline \multirow{5}{*}{ Pedroni } & V & -3.97 & -4.07 & -4.27 & -3.91 & -3.71 & -3.76 & -3.8 \\
& rho & 0.21 & 0.13 & 0.4 & 0.44 & 0.6 & 0.34 & 0.09 \\
& PP & $-6.06^{* * *}$ & $-6.12^{* * *}$ & $-5.08^{* * *}$ & -5.06 & $-5.77 * * *$ & $-6.06^{* * *}$ & $-6.64^{* * *}$ \\
& ADF & $-7.63^{* * *}$ & $-8.15^{* * *}$ & $-6.86^{* * *}$ & $-6.43^{* * *}$ & $-6.93^{* * *}$ & $-7.72^{* * *}$ & $-6.51^{* * *}$ \\
& rho & 1.24 & 1.23 & 1.46 & 1.75 & 1.49 & 1.09 & 1.03 \\
& PP & $-9.66^{* * *}$ & $-9.66^{* * *}$ & $-9.25^{* * *}$ & $-9.49^{* * *}$ & $-10.49^{* * *}$ & $-10.60^{* * *}$ & $-12.57 * * *$ \\
\hline \multirow{5}{*}{ Kao } & ADF & $-7.88^{* * *}$ & $-7.88^{* * *}$ & $-8.24 * * *$ & $-7.68^{* * *}$ & $-8.25 * * *$ & $-8.45^{* * *}$ & $-10.35^{* * *}$ \\
\hline
\end{tabular}

Note: Lag selection chosen according to Swartz Information Criterion; individual intercepts and trends assumed; $* * *$ p-value $<0.01$.

Table A5: Pairwise Causality Tests (Lags: 2) - entire sample

\begin{tabular}{lcc}
\hline Null Hypothesis: & W-Stat. & Prob. \\
\hline & & \\
ROL does not Granger cause GROWTH & 3.53741 & 0.0241 \\
GROWTH does not Granger cause ROL & 1.94596 & 0.4642 \\
& & \\
VAC does not Granger GROWTH & 4.26522 & 0.0003 \\
GROWTH does not Granger cause VAC & 1.80716 & 0.3210 \\
& & \\
COC does not Granger cause GROWTH & 3.68614 & 0.0112 \\
GROWTH does not Granger cause COC & 1.91139 & 0.4256 \\
& & \\
GOVEF does not Granger cause GROWTH & 2.87658 & 0.3100 \\
GROWTH does not Granger cause GOVEFF & 1.52163 & 0.1264 \\
& & \\
REG does not Granger cause GROWTH & 3.13053 & 0.1357 \\
GROWTH does not Granger cause REG & 1.86163 & 0.3733 \\
& & \\
POLST does not Granger cause GROWTH & 3.01800 & 0.2003 \\
GROWTH does not Granger cause POLSTB & 1.58841 & 0.1606 \\
\hline
\end{tabular}


Note: We reject the null that ROL, VAC and COC do not homogeneously cause GROWTH, but we cannot reject the null in the opposite direction. In the case of GOVEFF, REG and POLSTB we cannot reject the null in both directions.

Table A6: Pairwise Causality Tests (Lags: 2) - entire sample

\begin{tabular}{lcc}
\hline Null Hypothesis: & F-Statistic & Prob. \\
\hline & & \\
LSPRIV does not Granger Cause GROWTH & 10.8277 & $3 . \mathrm{E}-05$ \\
GROWTH does not Granger Cause LSPRIV & 5.26557 & 0.0055 \\
& & \\
SSPRIV does not Granger Cause GROWTH & 5.31021 & 0.0053 \\
GROWTH does not Granger Cause SSPRIV & 1.94200 & 0.1446 \\
& & \\
GER does not Granger Cause GROWTH & 9.88390 & $6 . \mathrm{E}-05$ \\
GROWTH does not Granger Cause GER & 1.60662 & 0.2017 \\
& & \\
PRLIB does not Granger Cause GROWTH & 5.71381 & 0.0035 \\
GROWTH does not Granger Cause PRLIB & 13.2848 & $2 . \mathrm{E}-06$ \\
& & \\
TFX does not Granger Cause GROWTH & 8.16302 & 0.0003 \\
GROWTH does not Granger Cause TFX & 0.56172 & 0.5706 \\
& & \\
COMPOL does not Granger Cause GROWTH & 10.1136 & $5 . \mathrm{E}-05$ \\
GROWTH does not Granger Cause COMPOL & 0.86020 & 0.4238 \\
\hline
\end{tabular}

Note: We reject the null that LSPRIV, SSPRIV, GER, PRLIB, TFX and COMPOL does not Granger cause GROWTH. Also, we reject the null that GROWTH does not Granger cause LSPRIV and PRLIB (bidirectional relationship). However, we cannot reject the nul that GROWTH does not Granger cause GER, TFC and COMPOL. 